\title{
Pendulous Crop in Broilers
}

http://dx.doi.org/10.1590/1516-635×1703395-398

Technical Note

\section{-Author(s)}

\section{Ebling PD'}

Pontalti GC

Villanueva AP

Ribeiro $A M L^{\prime}$

Universidade Federal do Rio Grande do Sul

\section{-Mail Address}

Corresponding author e-mail address Patrícia Diniz Ebling

Department of Animal Science and Animal Science Graduate Program, Universidade

Federal do Rio Grande do Sul, Bento Gonçalves Ave., 7712, Porto Alegre-RS Email: pati_sps@yahoo.com.br

\section{EKeywords}

Metabolic disorders, genetic improvement, feed intake voracity.

\section{ABSTRACT}

Pendulous crop is a physiological disorder, which etiology is still unknown and it is characterized by abnormal dilation of the crop of poultry. This article aims at reporting a case of high incidence of pendulous crop in male and female broilers Cobb 500, as well as to discuss its possible causes and consequences. In an experiment with broilers performed at the experimental facilities of Laboratório de Ensino Zootécnico of UFRGS, a high incidence (9.5\%) of pendulous crop was observed. Genetic predisposition is the most frequently documented and accepted cause of that condition. Despite presenting the same live weight as normal broilers, birds with pendulous crop had lower carcass weight due to dehydration and malnourishment, and should be culled after diagnosis. Therefore, further studies on the origin and control of this physiological disorder are warranted.

\section{INTRODUCTION}

Metabolic disorders may cause mortality in broilers, and consequently determine severe economic losses in poultry production. These disorders are caused by failures in the physiological response of organs and systems and are related to production systems (Jaenisch et al., 2001). Broilers are the most susceptible poultry category to metabolic disorders due to the characteristics of the industrial production system, together with the intensive genetic improvement to which they have been submitted during the last decades to increase their body protein deposition efficiency. Among other metabolic disorders that affect broilers, the incidence of pendulous crop has increased and it is a cause of concern of broiler companies.

Its etiology is still unknown. In some cases, it is associated with Marek's disease or with the presence of parasites (Reis, 1967). However, this disorder is also observed in healthy flocks, which suggests the involvement of genetic factors (El-lbiary \& Shaffner, 1950). The crop of the affected broilers is stretched due to the accumulation of feed, causing some elastin fibers that bind the muscle layers to break and affecting the vagus nerve (Macari et al., 2008). The damaged muscles are then unable to push the feed to the proventriculus, which may cause dehydration and malnourishment. To date, there is no treatment and birds presenting this condition early in the rearing period should be culled.

In an experiment with broilers, it was observed that many birds presented abnormal bulging of the crop, followed by feed intake reduction and dehydration symptoms. This article describes these observations.

\section{MATERIALS AND METHODS}

In a study with strain Cobb 500 broilers chickens at the experimental facilities of Laboratório de Ensino Zootécnico of UFRGS, a high incidence 
(9.5\%) of pendulous crop was observed during the entire experimental period, particularly after four weeks of age. In total, 336 broilers were reared in $1 \mathrm{~m}^{2}$ pens at 12 birds per pen on wood-shavings litter. A lighting program of $24 \mathrm{~h}$ continuous light was applied. Feed was fed as mash and formulated with adequate nutritional levels (Rostagno et al., 2011). Feed and water were supplied ad libitum from day 1. Nipple drinkers were used.
On day 40, eight birds presenting pendulous crop and five control birds were fasted for three hours, weighed, and sacrificed by neck dislocation. Live weight, body weight without the feathers, carcass weight, and crop content weight were evaluated.

Data were submitted to analysis of variance using the GLM procedure (General Linear Models) of SAS software program, version 9.0.

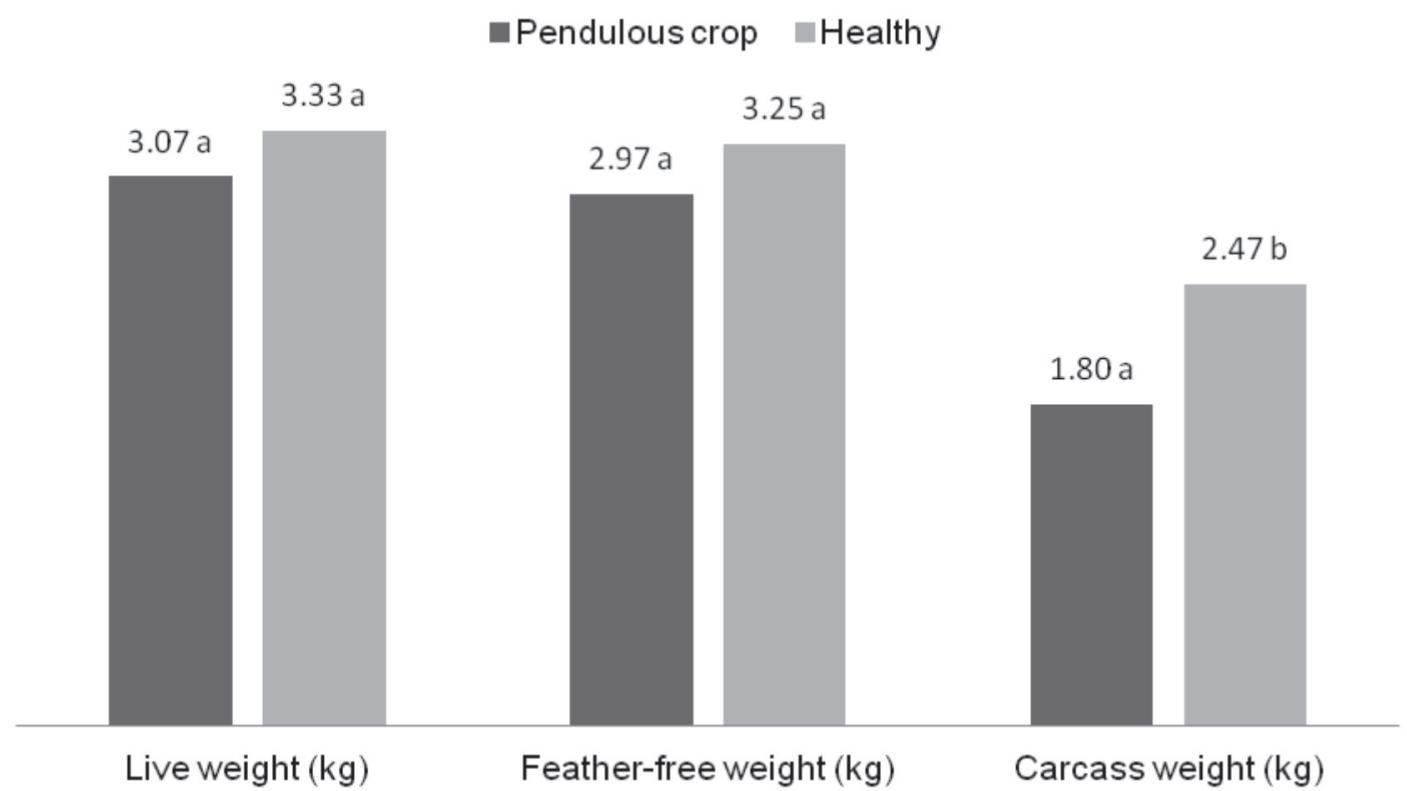

Figure 1 - Live weight, feather-free body weight, and carcass weight of broilers with pendulous crop and healthy broilers. Different letters indicate statistical difference by the t-test $(p<0.01)$.

\section{- Pendulous crop $\quad$ Healthy}

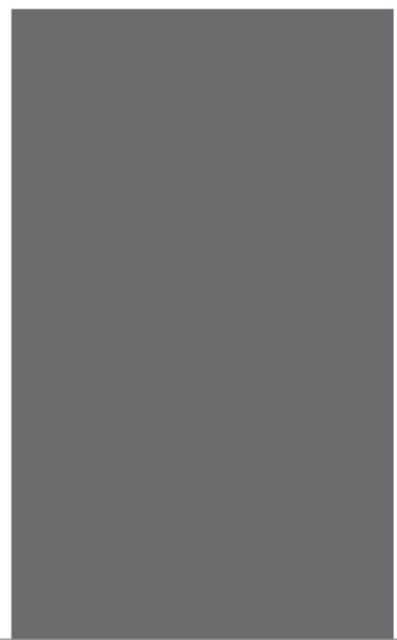

Crop content (g)

Figure $\mathbf{2}$ - Crop content weight of broilers with pendulous crop and healthy broilers. Different letters indicate statistical difference by the t-test $(p<0.01)$. 


\section{Pendulous Crop in Broilers}

\section{RESULTS AND DISCUSSION}

A $9.5 \%$ incidence of pendulous crop at various severity degrees and independently of sex was observed.

When comparing diseased with healthy birds, there were no statistical differences in live weight $(p>0.117)$ or feather-free body weight $(p>0.102)$. However, healthy birds presented heavier carcass weight (2.47 $\mathrm{kg}$ ) compared with those with pendulous crop (1.80 kg; $p<0.01$; Figure 1). Average crop content weight was lower $(0.008 \mathrm{~kg} ; \mathrm{p}<0.01)$ in the healthy birds than in those with pendulous crop (0.43 kg; Figure 2). Out of the eight birds with that condition, one bird presented a crop content of $0.82 \mathrm{~kg}$.

Although it is reported that broiler with pendulous crop may be malnourished and dehydrated, there were no evident symptoms or no live weight differences between the two groups. This result may be explained by the fact that broilers were reared in pens measuring only $1 \mathrm{~m}^{2}$, each equipped with a feeder and a drinker. The distances to the feeders and drinkers are much longer under field conditions. Large crop sizes change body balance point, hindering locomotion, and consequently leading broilers to consume less water and feed.

The $9.5 \%$ incidence of birds presenting pendulous crops observed in the present experiment is high and it is a cause of concern, as it results in performance losses and carcass downgrading. Despite the pre-slaughter fasting period, birds with that disorder presented accumulation of feed in the crop, which may cause carcass contamination in the processing plant (Vieira \& Russell, 2012).

Hinshaw \& Asmundson (1936) demonstrated that hereditability is the most important factor that determines the incidence of pendulous crop in turkeys, and may be associated with excessive water consumption during hot days. However, in the present study, broilers were housed in an environmentally controlled room, where temperature and air relative humidity was within the comfort range.

Genetic predisposition is the most frequently documented and accepted cause of pendulous crop in poultry. The intensive selection for feed intake and high growth rate may have inadvertently resulted in the expression of genes that hinder crop emptying, thereby causing pendulous crop.

The primary function of the crop is to store feed in birds living in environments where food is scarce, because the proventriculus and gizzard have limited storage capacity. However, considering industrial broiler production, where birds are fed ad libitum, the function of the crop is secondary (Svihus, 2014). The voracity of modern broiler strains may also explain the predisposition of this type of poultry for the development of pendulous crop. Considering that a broiler consumes approximately $4.88 \mathrm{~kg}$ of feed and the double amount of water during 40 days, the physical capacity of the crop may be limiting, and may not support the current feed intake capacity of the modern strains.

Another factor that may increase the incidence of pendulous crops is feed restriction, which could stimulate the voracity of birds at the time of feeding, resulting in high feed intake during a very short time. However, none of those hypotheses was proven.

Although in the present study broilers were reared under continuous lighting and were not feed-restricted in none of the rearing phases, thereby stimulating high feed intake, the expression of the genetic potential for pendulous crop is a cause of concern and should be further studied in order to determine its specific causes.

\section{CONCLUSIONS}

Male and female Cobb 500 broiler reared under continuous lighting and fed ad libitum with a standard feed presented high incidence of pendulous crop. Although presenting the same live weight, broilers with pendulous crop presented lower carcass weight as a function of the high feed content in the crop.

\section{REFERENCES}

El-Ibiary $H$, Shaffner CS. A genetic response to induced goiter in chickens. Journal of Heredity 1950; 41(9):246-247

Hinshawe WR, Asmundson VS. Observations on pendulous crop in turkeys. Journal of the American Veterinary Medical Association 1936;41:154165 .

Jaenisch FRF, Ávila VS, Mazzuco H, Rosa PS, Fiorentin L. Síndrome da hipertensão pulmonar: a ascite em frangos de corte. Concórdia: Embrapa Aves e Suínos, 2001. (Circular Técnica).

Macari M, Furlan RL, Gonzales E. Fisiologia aviária aplicada a frangos de corte. Jaboticabal: FUNEP; 2008.

Reis J. Doenças das aves. São Paulo: Edições Melhoramentos; 1967.

Rostagno HS, Albino LFT, Donzele JL, et al. Composição de alimentos e exigências nutricionais de aves e suínos: tabelas brasileiras. Viçosa: UFV; 2011.

Svihus B. Function of the digestive system. Journal Applied Poultry Research 2014;23:306-314

Vieira SL, Russell SM. Feed withdrawal strategies - and their impact on broiler chicken carcass yield and quality. In: Vieira SL, editor. Broiler carcass quality - An approach from the production sites. $2^{a}$ ed. São Paulo: Zinpro Corporation; 2012. p.11-22. 
